\title{
Proline rich regions of coenzyme A synthase $\alpha$ and $\beta$ interact with SH3 domains of signaling proteins in vitro
}

\author{
O. S. Breus ${ }^{1}$, G. G. Panasyuk ${ }^{1,2}$, I. T. Gout ${ }^{2}$, V. V. Filonenko ${ }^{1}$, I. O. Nemazanyy ${ }^{1}$ \\ ${ }^{1}$ Institute of Molecular Biology and Genetics, National Academy of Sciences of Ukraine \\ 150 Zabolotnogo Str., Kyiv 03680, Ukraine \\ ${ }^{2}$ Department of Biochemistry and Molecular Biology, University College London \\ Gower Street, London WC1 E6BT, UK \\ filonenko@imbg.org.ua
}

\begin{abstract}
Coenzyme A-synthases $\alpha$ and $\beta$ (CoASy $\alpha$ and CoASy $\beta)$ contain proline rich regions which may bring them into complexes with SH3-domain containing proteins. To test whether CoASy isoforms can bind to SH3 domains we performed in vitro pull down experiments. It was found that CoASy $\beta N$-terminal extension, which is especially abundant in prolines, can interact specifically and directly with SH3 domains of tyrosine kinases Fyn and CSK, phospholipase C $\gamma$, NADPH oxidase activator 1 - p67phox, and cytoskeleton protein spectrin. Furthermore, C-terminal SH3 domain of p67phox can also interact with SH3 binding site that resides on the shared part of CoASy $\beta$ and CoASy $\alpha$. These data demonstrated that CoA Synthases could be involved in complexes with signaling proteins in living cells which may regulate enzymatic activities of CoA Synthases or vice versa CoA Synthase may modulate some steps in signal transduction in the cell in currently unknown way.
\end{abstract}

Key words: CoA Synthase, SH3 domain, proline rich regions, signaling proteins.

Introduction. Coenzyme A (CoA) is ubiquitous cofactor essential for living, involved in numerous enzymatic reactions in cell. Reduced CoA and its acyland acetyl-derivatives play a key role in the energetic, carbohydrate, and lipid cell metabolism [1], regulation of transcription via histone acetylation [2], proteins acylation [3], and oxidative stress protection via cysteamine biosynthesis [1]. Both quantity and form of available CoA and its derivatives depend on cell type and cell compartment, and vary in different physiological circumstances [1].

It has been shown that the level of intracellular CoA is regulated by various extracellular stimuli including insulin, glucose, fatty acids, pyruvate, glucagon, and

(C) O. S. BREUS, G. G. PANASYUK, I. T. GOUT, V. V. FILONENKO,

I. O. NEMAZANYY, 2008 glucocorticoids [1, 6-8]. The rate of CoA biosynthesis changes with fasting, re-feeding, and several pathological conditions, such as diabetes, Reye syndrome, and cancer [1, 6-8].

However, very little is known about the pathways leading to such regulation. Up-to-date, the mechanisms of regulation are known only for the first enzymatic step in the pathway of CoA biosynthesis phosphorylation of pantothenate by pantothenate kinase (PanK). There are at least four PANK genes in human genome ( $h P A N K 1, h P A N K 2, h P A N K 3$, and $h P A N K 4)$ and at least two alternative splicing isoforms for PanK1 and PanK2. PanKs share the same catalytical core but are differently regulated by reduced $\mathrm{CoA}$ and its thioesters such as acetyl-CoA and acyl-CoA [4, 9-11]. Differential transcription of 
PANKs mRNA in response to different stimuli such as hypolipidemic agents, glucose, and lipids was also shown to modulate intracellular CoA level [10].

4'-phosphopantetheine is one of the major pantothenate metabolites in cell along with CoA and pantothenate itself. It means that CoA Synthase (CoASy), which utilizes 4'-phosphopantetheine to generate dephosphoCoA and CoA, may be the second rate limiting enzyme in the pathway of CoA biosynthesis [4]. Nevertheless, no physiological regulators of CoASy have been reported so far. Recently two isoforms of CoA Synthase - CoASy $\alpha$ and CoASy $\beta$ - have been cloned $[13,15]$. We have demonstrated that CoASy $\alpha$ associates specifically with ribosomal S6 kinase - one of the key regulators of cell size and growth. The association was observed between native and transiently overexpressed proteins in vivo [15]. New interactions with signaling molecules could uncover novel mechanisms of CoA biosynthesis regulation.

The distinctive feature of CoASy $\beta$ is a proline-rich 29 amino acids (29 aa) long N-terminal extension (Fig. 1, A). According to bioinformatic analysis this proline-rich sequence may bring CoASy $\beta$ into different signaling complexes with Src homology 3 (SH3) domain containing proteins in cell. SH3 domains are small modular domains about 60 amino acids in size. They function as adapters, mediating protein-protein interactions, and are common domains for proteins building signaling networks and for some cytoskeleton proteins. SH3 domains are found in a wide range of functionally distinct signaling proteins including adapter proteins, protein kinases, lipid kinases, GTPases, GAPs, GEFs, lipases, protein phosphatases, etc. These domains bind with moderate affinity and selectivity to proline-rich ligands and play critical roles in numerous biological processes ranging from regulation of enzymes by intramolecular interactions, increasing the local concentration or altering the subcellular localization of components of signaling pathways, and mediating the assembly of large multiprotein complexes [5].

In this paper, we show that full-length CoA Synthase $\alpha$ and $N$-terminal 29 aa extension of CoASy $\beta$ isoform can directly interact with $\mathrm{SH} 3$ domains of a number of signaling proteins in vitro.
Material and Methods. Bioinformatics. Scansite program was used for bioinformatical identification of protein motives, which could potentially bind to domains such as SH2 and/or SH3. Scansite search is based on the matrix of selectivity values for amino acids at each position relative to an orienting residue as determined by the oriented peptide library technique [11].

Plasmid Construction and Expression studies. The human EST clone 5187222, corresponding to the full length CoASy $\beta$, was received from I.M.A.G.E. consortium and verified by sequencing. The coding sequence corresponding to the first $\mathrm{N}$-terminal 29 aa of CoASy $\beta$ was amplified by PCR and cloned into $p E T 42 a$ vector ( Novagen», USA) in frame with GST and 6HIS (29 aa CoASy $\beta$ pET42a). 29 aa CoASy $\beta-p E T 42 a$ were expressed in Escherichia coli BL21 DE3 cells and recombinant protein was then purified using Ni-NTA agarose according to Ni-NTA Spin Handbook manual («Qiagen», USA).

Pull Down Experiments. In a pull-down assay, $1 \mathrm{~g}$ of 6His-GST, 6His-GST-29 aa CoASy $\beta$ fusion protein and His-CoASy $\alpha$ protein were incubated with Ni-NTA («Qiagen») for $2 \mathrm{~h}$ at $4{ }^{\circ} \mathrm{C}$ in a buffer for native condition (50 mM NaH $\left.\mathrm{PO}_{4}, \mathrm{pH} 8.0,300 \mathrm{mM} \mathrm{NaCl}\right)$. The beads were then washed with the binding buffer to remove unbound proteins and incubated at $4{ }^{\circ} \mathrm{C}$ for $3 \mathrm{~h}$ with $1 \mathrm{~g}$ of purified GST-SH3 domains [16]. Non-specific interactions were removed by washing with binding buffer and bound proteins were eluted by boiling in Laemmli sample buffer.

Immunoblot Analysis. Proteins were separated by SDS-PAGE and transferred onto polyvinylidene difluoride membrane. After that the membrane was incubated for $1 \mathrm{~h}$ in blocking solution (5\% non-skim dry milk in TBS/Tween $0.1 \%$ ). After blocking the membranes were cut on three pieces according to molecular weight marker to visualize $62 \mathrm{kDa}$ full length CoASy $\alpha-6$ His protein with CoASy specific antibodies, SH3 domains with molecular weights ranging from 55 to $30 \mathrm{kDa}$ with anti-GST antibodies or 28-25 kDa respectively 6His-GST-29 aa CoASy $\beta$, and 6 His-GST proteins with anti-6His antibodies. After washing with TBS, $0.1 \%$ Tween, the membrane was incubated for $1 \mathrm{~h}$ with secondary horseradish peroxidase-conjugated anti-mouse antibody («Prome- 


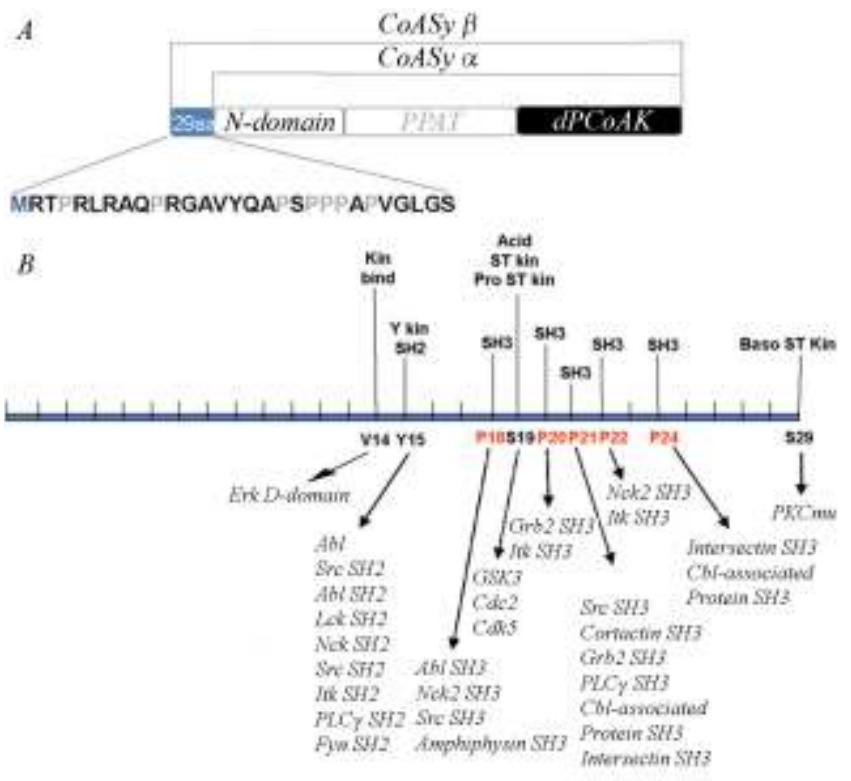

Fig. 1. Schematic representation of mammalian CoA Synthases: $A-$ domain organization of mammalian CoA Synthases $\alpha$ and $\beta$; dPCoAK - dephosphoCoA kinase domain; PPAT - phosphopantetheine adenylyltransferase domain; N-domain - N-terminal domains; amino acids are shown in the one letter code; $B$ bioinformatic prediction of interactive sites on CoASy $\beta \mathrm{N}$-terminal 29 aa extension. For prediction Scansite program was used (http://scansite.mit.edu)

ga»). The antigen-antibody complexes were detected using the ECL system («Amersham Biosciences»).

Results and Discussion. To elucidate specific function of CoASy $\beta$ isoform, which has 29 aa proline rich extension at the $\mathrm{N}$-terminus, we employed bioinformatical approach. Using a medium stringency Scansite [12] search, in both isoforms we revealed potential binding sites for $\mathrm{SH} 2 / \mathrm{SH} 3$ domains of different proteins. Moreover, recognition motives specific for SH3 domains of Crk, Abl, Nck2, PLC $\gamma$, Itk proteins were identified only in 29 aa N-terminal extension of the CoASy $\beta$, whereas $\mathrm{SH} 3$ domains of cortactin, Grb2, Src, amphiphysin, Cbl-associated protein and intersectin had predictive binding sites residing on the CoASy $\beta$ specific extension as well as on the part of molecule, shared by $\beta$ and $\alpha$ isoforms (Fig. 1, B). These predictions are an important indication of the possibility of CoASy involvement in complexes with signaling proteins in living cells.

At the next stage we tested interactions of full length CoASy $\alpha$ and CoASy $\beta$ specific 29 aa extension with SH3 domains of different intracellular proteins. For this purpose, we cloned cDNA coding for 29 aa fragment in frame with 5' sequence of GST-6His tag in pET42a vector («Novagen»). Fusion with GST-6His tags allowed 29 aa peptide to be expressed in bacteria and purified on Ni-NTA agarose («Qiagen») (Fig. 2, $B)$. Purified protein was tested in Western blotting with rabbit polyclonal antibodies generated against the synthetic peptide composed from the first $\mathrm{N}$-terminal 16 aa of CoASy $\beta$ [13] (Fig. 1, C).

To examine direct interactions of 29 aa CoASy $\beta$ peptide and full-length CoASy $\alpha$ with SH3 domains, we used a panel of $13 \mathrm{SH} 3$ domains originated from various mammalian proteins in pull down experiments. This panel was generated as SH3-GST fusion proteins expressed in E. coli. GST-6His-29 aa CoASy $\beta$ purified from bacteria and full-length $6 \mathrm{His}-\mathrm{CoASy} \alpha$ which was purified earlier in our laboratory using baculovirus system [13] were immobilized on Ni-NTA agarose. SH3-GST domains were added to the resin coated with the bait proteins, incubated for $2 \mathrm{~h}$ in binding buffer and

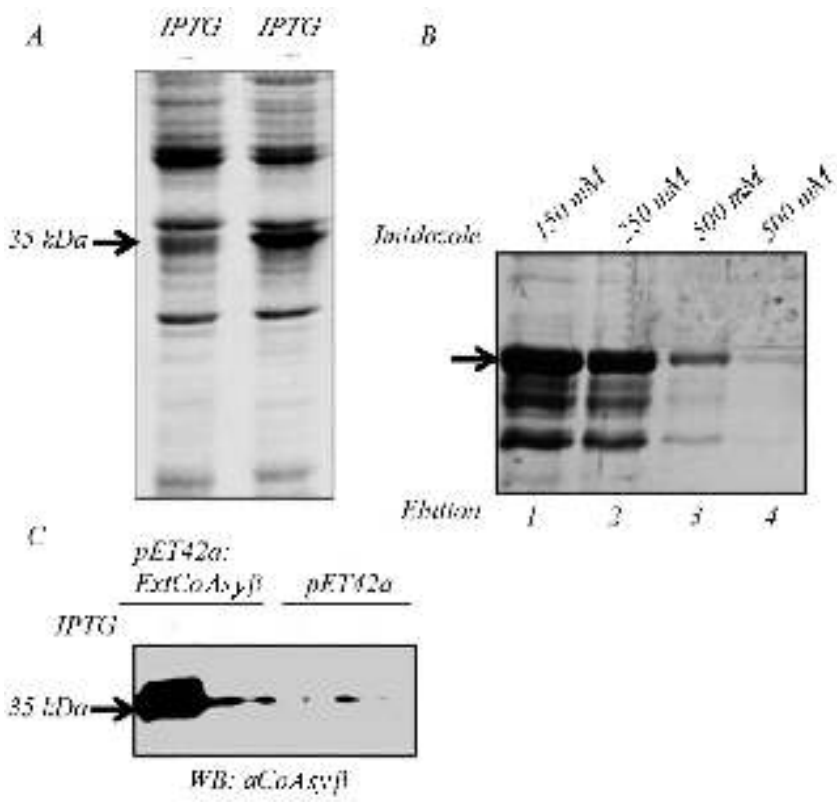

Fig. 2. Expression in E. coli and purification of GST-6His fused N-terminal 29 aa extension of CoASy $\beta$ : $A$ - PAGE of total lysates of BL-21 cells transformed with His-GST-29 a CoASy $\beta$ pET42a before or after induction with $100 \mu \mathrm{M}$ IPTG; Coomassie blue staining; $B$ - PAGE of His-GST-29 aa CoASy $\beta$ fractions eluted from Ni-NTA agarose with different imidazole concentrations; Coomassie blue staining; $C$ - Western blot analysis of purified 6 His-GST-29 aa CoASy $\beta$ protein with rabbit polyclonal antibodies to N-terminal peptide of CoASy $\beta$ 


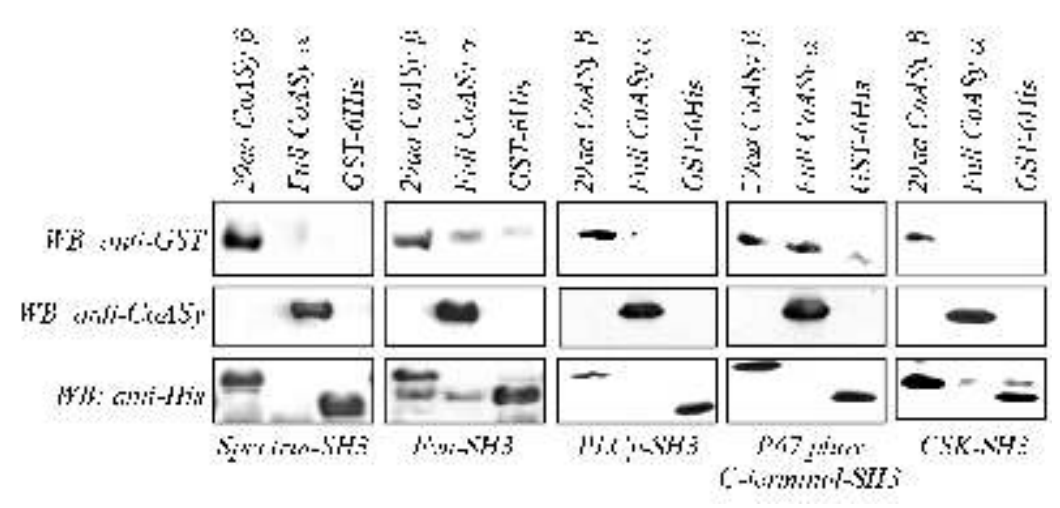

Fig. 3. In vitro binding of CoASy $\alpha$ and 29 aa $\mathrm{N}$-terminal extension of CoASy $\beta$ with SH3 domains of different proteins. The top panel, visualized with anti-GST antibodies shows binding of GST fused SH3 domains with immobilized 29 aa N-terminal extension of CoASy $\beta$ or full-length CoASy $\alpha$ or with control 6 His-GST protein. The middle panel, visualized with anti-CoASy antibodies, shows immobilized on Ni-NTA full-length 6His-CoASy $\alpha$ protein. The low panel, visualized with anti-6His antibodies shows, immobilized on Ni-NTA 6His-GST-29 aa N-terminal extension of CoASy $\beta$ and 6 His-GST protein

Summary of SH3 domains tested in the pull down experiment as direct interacting partners of CoASy $\beta$-terminal extension and full size CoAsy $\alpha$ protein

\begin{tabular}{|c|c|c|c|}
\hline Tested SH3 domains & $\begin{array}{c}\text { Binding to } \\
\mathrm{N} \text {-terminal extension } \\
\text { of CoASy } \beta\end{array}$ & $\begin{array}{r}\text { Binding to } \\
\text { CoASy } \alpha\end{array}$ & Protein function \\
\hline
\end{tabular}

Ruk1(SH3A)

Ruk1(SH3B)

Ruk1(SH3C)

Grb2

Spectrin
c-Src
p67phox

C-terminal

Fyn

Crk

Fgr

$\operatorname{PLC} \gamma$

GAP(Ras)

Csk

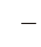

$-$

$-1$

Adapter protein involved in regulating diverse signal transduction pathways
Adapter protein mediating coupling of activated growth factor receptors with proline rich regions containing ligands

One of the key components of membrane skeleton involved in membrane trafficking

Non-receptor tyrosine protein kinase of Src family

NADPH oxidase activator 1

Non-receptor tyrosine protein kinase of Src family

\begin{abstract}
Adapter protein recruiting cytoplasmic proteins to the vicinity of tyrosine kinase
\end{abstract}

Non receptor tyrosine kinase of Src family
Phospholipase $\mathrm{C} \gamma$; Hydrolyzes phosphatidylinositol 4,5-biphosohate (PIP2) in response to various extracellular stimuli to produce two second messengers, diacylglycerol and inositol 1,4,5-triphosphate

GTPase activating protein of Ras

Non-receptor tyrosine protein kinase. Negatively regulates Fyn and other non receptor Src family tyrosine kinases 
washed. As a control, non-specific binding of SH3-GST domains to Ni-NTA agarose along with immobilized GST-6His was tested for each $\mathrm{SH} 3$ domain. Interaction of SH3-GST domains with immobilized proteins was analysed by Western blot with GST specific antibodies.

Specific binding of different SH3 domains with N-terminal 29 aa extension of CoASy $\beta$ and/or full-length CoAsy $\alpha$ was detected (Fig. 3). Table summarizes results obtained in the pull down experiment. We showed direct specific in vitro interactions of $\mathrm{N}$-terminal extension CoASy $\beta$ with $\mathrm{SH} 3$ domains of Src family non-receptor tyrosine kinases Fyn and Csk, phospholipase $\mathrm{C} \gamma$, NADPH oxidase activator 1 - p67phox, and structural membrane skeleton protein spectrin. Using GST-fused C-terminal SH3 domain of p67phox we showed that CoASy $\alpha$ can also directly interact with SH3 domains, and, contrary to N-terminal 29 aa proline rich sequence, has several separate proline rich motives. These data indicate that p67phox protein may have several binding sites on CoASy molecule, one of them located on $\mathrm{N}$-terminus of CoASy $\beta$ and others - within the shared part of CoASy $\alpha$ and $\beta$.

Noteworthy, in this experiment we confirmed interaction predicted by Scansite program for PLC $\gamma$ SH3 domain. However, we failed to detect interactions between CoASy and SH3 domains of tyrosine kinases Src, Crk, and adapter protein Grb2 predicted by ScanSite.

Although this type in vitro interaction experiments has to be validated for in vivo systems in co-immunoprecipitation experiments, we consider this approach to be suitable for primary screening of protein interactions. Our data indicate definitely that CoA Synthase isoforms can potentially form complexes with SH3 containing proteins involved in signal transduction in cell. Furthermore, CoASy $\beta$ isoform has an additional $\mathrm{N}$-terminal proline rich peptide. As it was demonstrated here, this proline rich peptide substantially extends the range of SH3 domains which can bind directly to CoASy. Whether these interactions interfere with regulation of the rate of Coenzyme A biosynthesis, intracellular localization of CoASy or with other intracellular functions remains to be elucidated.
Acknowledgments. Oksana Breus was supported by FEBS Collaborative Experimental Scholarships for Central \& Eastern Europe.

О. С. Бреус, Г. Г. Панасюк, І. Т. Гут, В. В. Філоненко,

I. О. Немазаний

Збагачені проліном області коензим А-синтаз $\alpha$ та $\beta$ взаємодіють з SH3 доменами сигнальних білків in vitro

Резюме

Кофермент А-синтази $\alpha$ та $\beta$ містять збагачені проліном ділянки, які можуть сприяти їхньому комплексоутворенню 3 білками, що містять SH3 домени. Для перевірки цієї гіпотези ми провели експерименти in vitro по зв'язуванню повнорозмірного білка КоА-синтази $\alpha$ та специфічного для КоА-синтази $\beta N$-кінцевого пептиду із SH3 доменами сигнальних білків. Виявилося, що специфічний для КоA-синтази $\beta N$-кінцевий пептид, багатий на пролін, специфічно взаємодіє з SH3 доменами тирозинових протеїнкіназ Fуn і CSK, фосфоліпази C $\gamma$, активатора NADPH оксидази 1 - p67phох і цитоскелетного білка спектрину. Крім того, SHз домен р67рhох зв'язується із збагаченою проліном послідовністю, спільною для обох ізоформ. Отримані результати дозволяють припустити, що КоА-синтази перебувають у комплексах з сигнальними білками $i$, таким чином, відбувається регуляція їхньої ферментативної активності або ж КоА-синтази невідомим на даний час способом модулюють певні етапи передавання сигналів у клітині.

Ключові слова: КоА синтаза, SH3 домен, області збагачені проліном, сигнальні білки.

О. С. Бреус, Г. Г. Панасюк, И. Т. Гут, В. В. Филоненко, И. А. Немазаный

Обогащенные пролином области кофермент А-синтаз $\alpha$ и $\beta$ взаимодействуют с SH3 доменами сигнальных белков в условиях in vitro

Резюме

Кофермент А-синтазы $\alpha$ и $\beta$ содержат богатые пролином области, возможно, способствующие их комплексообразованию с белками, содержащими SHЗ домены. Для проверки этой гипотезы мы провели эксперименты по связыванию in vitro полноразмерного белка КоА-синтазы $\alpha$ и специфического для КоА-синтазы $\beta N$-концевого пептида с SH3 доменами сигнальных белков. Оказалось, что пролин-богатый $N$-концевой пептид КоА-синтазы $\beta$ специфически взаимодействует с SH3 доменами тирозиновых протеинкиназ Fуn и CSK, фосфолипа-

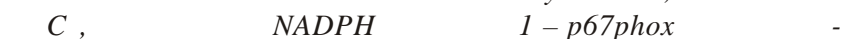
тоскелета спектрина. Кроме этого, SH3 домен р67phox взаимодействует с обогащенной пролином последовательностью, общей для обеих изоформ. Полученные результаты позволяют предположить, что КоА-синтазы $\alpha$ и $\beta$ образуют комплексы с сигнальными белками и, таким образом, регулируется ферментативная активность КоА-синтаз либо же КоА-синтазы неизвестным на данный момент способом модулируют определенные этапы передачи сигналов в клетке.

Ключевые слова: КоА-синтаза, SНЗ домен, области, обогащенные пролином, сигнальные белки. 


\section{REFERENCES}

1. Leonardi R., Zhang Y. M., Rock C. O., Jackowski S. Coenzyme A: Back in action // Progr. Lipid Res.-2005.-44.-P. 125-153.

2. Takahashi H., McCaffery J. M., Irizarry R. A., Boeke J. D. Nucleocytosolic acetyl-coenzyme A synthetase is required for histone acetylation and global transcription // Mol. Cell.-2006.-23, N 2.-P. 207-217.

3. Linder M. E., Deschenes $R$. J. Palmitoylation: policing protein stability and traffic // Nat. Rev. Mol. Cell Biol.2007.-8, N 1.-P. 74-84.

4. Rock C. O., Calder R. B., Karim M. A., Jackowski S. Pantothemate kinase regulation of the intracellular concentration of Coenzyme A // J. Biol. Chem.-2000.-275, N 2.-P. 1377-1383.

5. Mayer B. J. SH3 domains: complexity in moderation // J. Cell. Sci.-2001.-114, N 7.-P. 1253-1263.

6. Kondrup J., Grunnet N. The effect of acute and prolonged ethanol treatment on the contents of coenzyme A, carnitine and their derivatives in rat liver // Biochem. J.-1973.-132.P. 373-379.

7. Lund H., Stakkestad J. A., Skrede S. Effects of thyroid state and fasting on the concentrations of CoA and malonyl-CoA in rat liver // Biochim. et Biophys. Acta.-1986.-876.P. 685-687.

8. Wittwer C. T., Beck S., Peterson M., Davidson R., Wilson D. E., Hansen R. G. Mild Patothenate deficiency in rats elevates serum triglyceride and free fatty acid levels // J. Nutr.-1990.-120.-P. 719-725.

9. Rock C. O., Karim M. A., Zhang Y. M., Jackowski S. The murine pantothenate kinase (Pank1) gene encodes two differentially regulated pantothenate kinase isozymes // Gene.-2002.-291, N 1.-P. 35-43.
10. Ramaswamy G., Karim M. A., Murti K. G., Jackowski S. PPARalpha controls the intracellular coenzyme A concentration via regulation of PANK $1 \alpha$ gene expression // J. Lipid Res.-2004.-45, N 1.-P. 17-31.

11. Zhang Y. M., Rock C. O., Jackowski S. Feedback regulation of murine pantothenate kinase 3 by coenzyme A and coenzyme A thioesters // J. Biol. Chem.-2005.-280, N 38.-P. 594-601.

12. Obenauer J. C., Cantley L. C., Yaffe M. B. Scansite 2.0: Proteome-wide prediction of cell signaling interactions using short sequence motifs // Nucl. Acids Res.-2003.-31, N 13.-P. 3635-3641.

13. Nemazanyy I., Panasyuk G., Breus O., Zhyvoloup A., Filonenko V., Gout I. T. Identification of a novel CoA synthase isoform, which is primarily expressed in the brain // Biochem. and Biophys. Res. Communs.-2006.-341, N 4.P. 995-1000.

14. Zhyvoloup A., Nemazanyy I., Panasyuk G., Valovka T., Fenton T., Rebholz H., Wang M. L., Foxon R., Lyzogubov V., Usenko V., Kyyamova R., Gorbenko O., Matsuka G., Filonenko V., Gout I. T. Subcellular localization and regulation of coenzyme A synthase // J. Biol. Chem.-2003.-278, N 50.-P. 50316-50321.

15. Nemazanyy I., Panasyuk G., Zhyvoloup A., Panayotou G., Gout I. T., Filonenko V. Specific interaction between S6K1 and CoA synthase: a potential link between the mTOR/S6K pathway, CoA biosynthesis and energy metabolism // FEBS Lett.-2004.-578, N 3.-P. 357-362.

16. Gout I., Dhand R., Hiles I. D., Fry M., Panayotou G., Das P., Truong O., Totty N., Hsuan J., Booker G., Campbell I., Waterfield $M$. The GTPase dynamin binds to and is activated by a subset of SH3 domains // Cell.-1993.-75, N 1.-P. 25-36.

УДК 577.2, 577.1

Надійшла до редакції 30.10.07 